Original Research Paper

\title{
Growth Performance Serum Biochemical and Hematological Parameters of Lambs Fed with Ration Containing Nigella Sativa Meal in Different Feed Forms
}

\author{
${ }^{1}$ Nisa Nurmilati Barkah, ${ }^{2}$ Yuli Retnani, ${ }^{2}$ Komang Gede Wiryawan and ${ }^{1}$ Annisa Rosmalia \\ ${ }^{1}$ Study Program of Nutrition and Feed Sciences, Postgraduate School, Bogor Agricultural University, Bogor, West Java, Indonesia \\ ${ }^{2}$ Department of Nutrition and Feed Technology, Bogor Agricultural University, Bogor, West Java, Indonesia
}

\author{
Article history \\ Received: 22-11-2020 \\ Revised: 25-05-2021 \\ Accepted: 19-07-2021 \\ Corresponding Author: \\ Komang Gede Wiryawan \\ Department of Nutrition and \\ Feed Technology, Bogor \\ Agricultural University, Bogor, \\ West Java, Indoensia \\ Email: kgwiryawan61@gmail.com
}

\begin{abstract}
Nigella Sativa Meal (NSM) as a byproduct from Nigella sativa oil production contains high crude protein, but it is easily converts into ammonia $\left(\mathrm{NH}_{3}-\mathrm{N}\right)$ in the rumen. The processing of feed containing NSM into mash, pellet and wafer forms is expected to optimize the use of NSM as a protein source in feed. The objective of this study was to evaluate the feed containing Nigella Sativa Meal (NSM) feeding in three different form song rowth performance, serum biochemical and hematological parameters of lamb. This study used a Randomized Block Design (RBD) with 3 treatments of feed forms: Mash (M), Pellet (P) and Wafer (W)and 5 replications. The concentrations of NSM in the rations were $20 \%$ with the same formulation in all treatments. The forage to concentrate ratio was 30:70. The results showed that different forms of feed has significant effect on crude protein and crude fiber intake, blood triglycerides and Blood Urea Nitrogen (BUN) concentration $(p<0.05)$. Feed in mash form resulted in higher body weight gain compared to other treatments with the average daily weight gain of mash $(120.96 \mathrm{~g})$, pellet $(117.23 \mathrm{~g})$ and wafer $(119.80 \mathrm{~g})$. Feed in pellet form produced better feed efficiency compared to other treatments, with an average efficiency of pellet $(9.89 \%)$, wafer $(9.46 \%)$ and mash $(8.71 \%)$.
\end{abstract}

Keywords: Black Seed, Habbatussauda, Mash, Pellet, Wafer

\section{Introduction}

Exploration and diversification of protein source feed material are important to substitute the main feed commonly used in ration such as soybean meal. Habbatussauda (Black Seed) isfamous as herbs which areprocessed for its oil. The waste of habbatussaudaor commonly called Nigella Sativa Meal (NSM) or Nigella sativa cake, which is derived from habbatussauda oilindustry with pressing methods contains dry matter 91.9\%, crude protein 23.3 and ash 9.6\% (Ali et al., 2012). The NSM also contains several minerals such as $\mathrm{Mg}, \mathrm{Fe}$, $\mathrm{Cu}, \mathrm{Ca}$ and $\mathrm{K}$ (Cheikh-Rouhou et al., 2007).

NSM has the potentia to be used as feed material for protein source because of high crude protein content in it. In ruminants, when feed protein sources enter the rumen, the protein will be degraded into ammonia $\left(\mathrm{NH}_{3}-\mathrm{N}\right)$ which can be used by rumen microbes for microbial protein synthesis. The ammonia absorbed from the rumen will be converted into urea by the liver and will be distribute to the blood and the extracellular space, excluding gastro intestinal tract water and eventually lost through urine (Colmenero and Broderick, 2006). The results of Gustian (2017) stated that the use of NSM as much as 10 and $20 \%$ in feed increased the performance of Indonesian local lamb. This indicates that the NSM has a good nutrient content to improve the performance of lamb. However, the results of Barkah et al. (2017) stated that the use of NSM with levels of 10 and $20 \%$ in the ration significantly increased Blood Urea Nitrogen (BUN) levels. High levels of BUN indicate that NSM addition in feed increasee protein degradation in the rumen which can lead to inefficient of protein utilization due to excessive degradation of protein before it is used and absorbed in intestines.Increased levels of dietary protein significantly increased BUN levels (Norrapoke et al., 2012), rumen $\mathrm{NH}_{3}-\mathrm{N}$ concentration (Abadi et al., 2015), urinary $\mathrm{N}$ excretion (Leonardi et al., 2003) and decreased the efficiency of $\mathrm{N}$ utilization (Danes et al., 2013). It will causing economic loss, adverse environmental effects and possibly some metabolic diseases (Nocek, 1997). 
$\mathrm{N}$ utilization in ruminant feed can be optimized by combining it with Readily Available Carbohydrate (RAC). According to Ranjhan (1977) RAC can stimulate microbial growth in the rumen which also causes the high use of $\mathrm{NH}_{3}-\mathrm{N}$ for microbial growth so the total $\mathrm{NH}_{3}-\mathrm{N}$ converted into urea will be reduced. The combination of NSM and RAC pollard produces optimal in vitro fermentability because the resulting concentrations of VFA and $\mathrm{NH}_{3}-\mathrm{N}$ are suitable to support microbial protein synthesis (Barkah et al., 2019). Moreover, various feed processing technologies have developed with various objectives, including increasing nutrient use, maintaining feed quality, increasing feed efficiency and reducing anti-nutritional substances (Retnani et al., 2020)

Feed processing technology that has evolved are pelleting and wafering. Diets containing the same nutrients given in different forms (mash, pellets and blocks) can affect feed intakeand nutrient digestibility, feed fermentation patterns in the rumen, body weight and feed conversion ratio (Karimizadeh et al., 2017), retention of calcium and phosphorus minerals, digestibility of dry matter and organic matter, crude protein, NDF and ADF. Differences in feed form can affect animal eating behavior and fermentation process in the rumen. The compression in pelleting process causes an increase in agglomeration and hardness of feed particles which affect the rumination behavior, especially in the chewing process which is longer than the feed in the form of mash (Bertipaglia et al., 2010). This research aims to evaluate the feed containing NSM in different feedforms (Mash, Pellets and Wafer) onperformance, serum biochemical and hematological parameters of lambs.

\section{Materials and Methods}

\section{Formulationand Feed Processing}

Ingredients were formulated based on the nutrient requirements for 5 month old lamb with body weight $20 \mathrm{~kg}$ anddaily weight gain $150 \mathrm{~g} \mathrm{head}^{-1}$ day $^{-1}$ which was recommended by Kearl (1982). The feed ingredients and nutrient content can be seen in Table 1 .

The feed ingredients in Table 1 were mixed with the use of mixer machine. Before all the ingredients were mixed, NSM were milled by grinder with a diameter of die $6 \mathrm{~mm}$. Then, feed concentrate is divided into 3 forms: Mash, pellet and wafer.Process of pelleting use a pelleter machine with diameter die $5 \mathrm{~mm}$ and a pellet size of $2 \mathrm{~cm}$. Before that, the materials were added with water $\pm 300 \mathrm{~mL}$ $\mathrm{kg}^{-1}$ feed ingredients and mixed for $10 \mathrm{~min}$ in the mixer machine. After processing, the pellets were dried in the oven with temperature $60^{\circ} \mathrm{C}$ for $4 \mathrm{~h}$. Wafers were made using wafer machine with pressing and heating technique at $80^{\circ} \mathrm{C}$ for $10 \mathrm{~min}$. The wafer size is $8 \times 8 \times 8 \mathrm{~cm}$. Feed were packed in a sack and stored in aclean warehouse.

\section{Climate and Weather Conditions}

The climate at the experimental site was humid tropical, with an average temperature and Relative Humidity (RH) in the morning, afternoon and evening during the study were $24.38^{\circ} \mathrm{C}$ and $99 \%, 32.15^{\circ} \mathrm{C}$ and $70.41 \%$ and $29.24^{\circ} \mathrm{C}$ and $77.45 \%$, respectively.

\section{Experimental Animals and Feeding Trial}

Fifteen Indonesian local male lamb 5 months of age with the average initial body weight $21.06 \pm 2.68 \mathrm{~kg}$ were randomy assigned to 3 treatments different feed forms: M (Mash), P (Pellet) and W (Wafer) comprising 5 replicates with 1 animal per replicate. The lamb were kept in individual pens for 65 days. Water was provided ad libitum. Adaptation period was 2 weeks allowing the lamb to adapt to the new feed. Before adaptation period, $2 \mathrm{~mL}$ Albendazole was orally administered to each lambto minimize disease due to worm infection.

Feed wasfed to the lamb by ad libitum. Ratio of the forage and concentrate given is 30:70. The forage were given one hour after harvest to reduce its moisture content. Everyday the lambwere given feed 4 times by making a turn between concentrates and forage. Feed remaining after one day was weighed every next morning by separating between feed concentrate and forage.

Table 1: Feed ingredients and nutrient content containing NSM with RAC combinations

\begin{tabular}{lc}
\hline Ingredient & Formula \\
\hline Field grass & 30.00 \\
Pollard & 24.50 \\
Rice bran & 22.05 \\
Nigella sativa meal & 19.60 \\
Molasses & 2.80 \\
$\mathrm{CaCO}_{3}$ & 0.70 \\
Premix & 0.35 \\
Nutrient Content ${ }^{\mathrm{a}}$ & \\
Dry matter $(\%)$ & 67.89 \\
Ash $(\%)$ & 7.09 \\
Crude protein $(\%)$ & 12.70 \\
Ether extract $(\%)$ & 2.27 \\
Crude fiber $(\%)$ & 15.23 \\
Nitrogen free extract $(\%)$ & 62.71 \\
Total digestible nutrient ${ }^{\mathrm{b}}(\%)$ & 66.92 \\
\hline
\end{tabular}

${ }^{\mathrm{a}}$ Estimated results of calculations based on the nutrient content of each ingredient. ${ }^{\mathrm{b}}$ Total Digestible Nutrient (TDN)in concentrate and grass is calculated using Wardeh (1981). TDN content ingrass $(\%)=1.6899+(1.3844 \times \%$ CP $)-(0.8279 \times \%$ EE $)+(0.3673 \times \%$ CF $)+(0.7526 \times \%$ NFE $)$; TDN content inconcentrate $(\%)=2.6407+(0.6964 \times \%$ CP) $-(1.2159 \times \%$ EE $)+(0.1043 \times \%$ CF $)+(0.9194 \times \%$ NFE $)$. $\mathrm{CP}$ is crude protein, EE is ether extract, $\mathrm{CF}$ is crude fat and NFE is nitrogen free extract 


\section{Evaluation of Growth Performance, Serum Biochemical and Hematological Parameters of Lambs}

Evaluation of lamb growth performance was measured through nutrient intake, average daily gain, efficiency of ration usage and Income Over Feed Cost (IOFC). Nutrient intakewas calculated based on the feed intake with nutrient content in it. The calculated nutrient intakeis Dry Matter Intake (DMI), Crude Protein (CP), Ether Extract (EE), Crude Fiber (CF) and the Nitrogen Free Extract (NFE). The lamba Average Daily Gain (ADG) was performed every 2 weeks to determine the weight gain.Efficiency value can be obtained from feed intakeand weight gain during maintenance. The IOFC value was calculated to know the profitgained after the maintenance process. The IOFC value was based on the purchase and selling price of lamb and feeding cost during research period. The purchase and sellingprice of lambwas obtained from the price in effect in February 2019 in the Bogor market, West Java, Indonesia:

\section{IOFC $=$ Selling price of lamb - (purchase price of lamb + feed cost during research period)}

Blood samples were taken at the 8th week after the treatment to analyze metabolite profiles and blood hematology of lambs. Blood was taken through the jugular vein on the neck by using a $5 \mathrm{~mL}$ syringewith the size of the needle $22 \mathrm{G} \mathrm{X} 1 \frac{1}{2}$;"; : parts of the neck was cleaned with a cotton $70 \%$ alcohol. The blood that has been taken was inserted into the 2 types of vacutainer tubes, there are the vacutainer tubes that have contained the EDTA anticoagulants (Ethylen Diamine Tetra Acetate) and the vacutainer tubes containing the gel separator (Serum Separator Tube/SST). Blood is inserted into cooler and brought to the laboratory to analyze the profile of metabolites and blood hematology.

The blood metabolites measured were glucose, triglycerides and BUN; based on enzymatic reactions using Clinical Chemistry Analyzer (Selectra Yunior). Blood serum samples were taken in the vacutainer tubes containing the gel separator (Serum separator tube/SST). Analysis of blood glucose based on GOD-PAP (Glucose Oxsidase-Peroxidase Aminotypirin) method at a wavelength of $500 \mathrm{~nm}$ (Subiyono et al., 2016). Analysis of blood triglycerides based on GPO Method-PAP (Glyceryl Phospo-Para Amino Phenazone) at $500 \mathrm{~nm}$ wavelengths (Hardisari and Koiriyah, 2016). Blood glucose and triglyceride analysis results were directly printed. Blood urea analysis based on Urease method was done at $340 \mathrm{~nm}$ wavelength (Widihastono, 1993). Results of blood urea analysis was converted to Blood Urea Nitrogen (BUN). The blood hematology analysis measured the number of erythrocites according to the method of Sastradipradja et al. (1989). Meanwhile, analysis the number of leukocytes and hemoglobin level were measured using Hematology Analizer (Medonic) according to the method Nathalie et al. (2009).

\section{Statistical Analysis}

Data obtained from this study were analyzed using ANCOVA (Analysis of Covariance) with initial body weight of lamb as covariate through SPSS v20.0 and the significantly different data were continued withBonferroni test.

\section{Results and Discussion}

\section{Chemical Composition}

The processingof concentrate feed into mash, pellets and wafers forms affects the nutrient content. The nutrient content of concentrate in mash, pellets and wafers forms can be seen in Table 2. The process of heating the pellets in an oven at $50^{\circ} \mathrm{C}$ for $4 \mathrm{~h}$ after forming, reduced the protein content by $2.04 \%$ compared to the protein content of the concentrate in mash form. Meanwhile, the wafering process with a temperature of $80^{\circ} \mathrm{C}$ for 10 min reduced protein content by $7.19 \%$ compared to the protein content of the concentrate in mash form. Protein content decreases with increasing heating temperature due to protein denaturation in feed (Novia et al., 2011). According to wet and dry heating processes in feed processing can change the structure of the protein molecule. Processing of feed into pellets and wafers can change the structure of the protein as a result of the heating and pressing process (Salazar-Villanea et al., 2016). According to Trisyulianti et al., (2001) the wafering process by pressing at a temperature of $120^{\circ} \mathrm{C}$, a pressure of $120 \mathrm{~kg} \mathrm{~cm}^{-2}$ with a time of $10 \mathrm{~min}$ can change the nutrient content in the ration. Processing with heat will reduce protein digestibility by reducing protein solubility in digestion media, due in part to crosslinking of peptide chains (Broderick, 1977), increase availability of starch due to the process of gelatinization (Solanas et al., 2005; Svihus et al., 2005), thus increasing the level of fermentation in the rumen (Bertipaglia et al., 2010).

\section{Nutrient Intake}

The process of feed processing into mash, pellet and wafer forms has no effect on DM, EE and NFE intake of forage $(\mathrm{P}<0.05)$. This indicates that the feed processing didnot interfere with lamb palatability to feed, so it didnot affect on feed intake. In this research, it is suspected that antinutrition in NSM is low, so the DM intake remains the same despite the differences of feed processing.

The data in Table 3 show that the feed processing into a mash, pellet and wafer significantly affected the $\mathrm{CP}$ intake of forage $(\mathrm{P}<0.05)$. This difference can be caused by several factors, including different maintenance periods, physiological conditions of animal and environmental conditions. CP intake with mash formwas 
higher than that of wafer and pellet forms. CP intakewas influenced by DM intake of concentrate and crude protein content in concentrate feed. Table 2 shows that the different feed forms processing caused a decrease in crude protein content compared to feed in mash form. Then, in Table 3, although there was no significant difference from each treatment, feed in mash form has a higher of DM intake compared to the form of pellets and wafers. The high content of crude proteinand DM intake in mash form led to the increased CP intake. According to NRC (2006) crude protein requirementof lambs with weight 10-20 kg anddaily body weight gain of 100-150 $\mathrm{g} \mathrm{head}^{-1}$ day $^{-1}$ is 70-104 $\mathrm{g} \mathrm{head}^{-1}$ day $^{-1}$. The total crude protein intake in each treatment was relatively higher than the crude proteinrequirement recommended by NRC (2006), is 151$184 \mathrm{~g} \mathrm{head}^{-1}$ day $^{-1}$.It can be caused by the high need of CP for maintanance and needs CP for average daily gain in Indonesian local lambwhich one of them related to the high temperature in the tropics (Jayanegara et al., 2017). Crude fiber (CF) intake of forage and total crude fiber intake in this study were not significantly affected (P> 0.05) by the treatments. However, the difference in feed form had a significant effect $(\mathrm{P}<0.05)$ on the $\mathrm{CF}$ intake of concentrate. $\mathrm{CF}$ intake in mash forms is higher than pellets and wafers. CF intake is influenced by DMI of concentrate and CF content in the feed. Table 2 shows that there is a decrease in CF content in the concentrate form of pellets and wafers compared to mash as a result of the processing of feed forms. According to Porter et al. (2007) the form of mash feed has a higher percentage of crude fiber digestibility than pellets. The average $\mathrm{CF}$ intake will increase along with the increase in $\mathrm{CF}$ content and DMI. The average intake of total CF in this study was around $17.53 \%$ of the DMI of the ration. According to Parakkasi (1999) the CF requirement oflambs ranges from $12-14 \%$. This shows that the need for crude fiber has been met properly. High crude fiber content in feed will increase mastication activity in animal and affect feed digestibility (Lu et al., 2005; Tillman et al., 1998).

\section{Body Weight Gain}

Table 4 shows that Average Daily Gain (ADG) tends to be the same in every treatment. This result is different from the research conducted by Karimizadeh et al., (2017) stating that feeding in the form of block feed produces the best ADG compared to the feed in the form of mash and pellet. ADG that tends to be the same is suspected because of the environmental conditions that lack support for lamb growth performance, especially during the daytime high temperature exceeds the comfortable temperature limit for lamb and because of the high humidity in the morning reaches $99 \%$. The efficiency of feed and IOFC also does not differ significantly with the different feed forms.

Selling price and purchase price of lamb based on market price in December-February 2019 amounted to RP
$75000 \mathrm{~kg}^{-1}$, concentrate price in the form of mash Rp 3191 $\mathrm{kg}^{-1}$, pellet Rp $4691 \mathrm{~kg}^{-1}$ and wafer Rp $4191 \mathrm{~kg}^{-1}$. The grass price is $\mathrm{Rp} 500 \mathrm{~kg}^{-1}$. The cost of feeding on pellet and wafer treatment is higher due to the addition of advanced feed processing costs. Although the results are not significant, the feed in the form of mash produces IOFC relatively higher than other form feed but has the lowest feed efficiency.

\section{Blood Metabolite Profiles}

Blood metabolite profiles describes the results of nutrient metabolism utilized by the body and serves as a source of energy, replacing damaged tissues and growth (McDonald et al., 2002).

Table 5 shows that different feed formsdid notsignificantly affect $(\mathrm{P}>0.05)$ blood glucose levels, but significantly affected $(\mathrm{P}<0.05)$ on triglyceride levels and BUN levels of lamb. Blood triglyceride levels in mash form are higher than in pellet and wafer forms. Blood triglyceride levels were influenced by the intake of fats and carbohydrates in feed (Soehardi, 2004; Tsalissavrina et al., 2006). Carbohydrate intake also contributes to the increased levels of Fructose 2.6biphosphate so that phospholifructokinase-1 becomes more active and stimulate glycolysis reactions. This increasing reaction of glycolysis will cause glucose to be converted into fatty acids as well. Free fatty acids together with glycerol form triacylglycerol. The higher the carbohydrate consumed, the higher the level of triacylglycerol in the blood (Marks, 2000).

The differences in the feed concentrate of mash, pellet and wafer affected the level of BUN in local lamb's blood $(\mathrm{P}<0.05)$. The pellet form treatment has a lower BUN rate compared to the mash and wafer forms. The compression process in pelleted feed causes the feed to have a more compact form than other forms of feed. This causes the pellet form to be chewed longer than other forms, so that the flow rate of the pellet takes longer to enter the rumen. This causes the protein degradation process to be slower, which causes the conversion of ammonia to BUN also longer, so that the BUN content in the pellet form is lower than mash and wafer forms. BUN content reflects protein intake, the ratio of protein intake to the fermentation of organic matter in the rumen and also serves as an indicator of the status of proteins. Increased of proteins intake will increase the level of BUN (Martin et al., 2005). BUN levels are positively correlated to the $\mathrm{NH}_{3}-\mathrm{N}$ level in the rumen (Javaid et al., 2008). The process of protein degradation will produce excess ammonia and is subsequently absorbed by the rumen wall and through the circulation of blood to the liver to undergo the process of change into urea, then through the blood circulation, some of the urea will be secreted into saliva and partly other unused to the kidneys to be secreted via urine (Tillman et al., 1998). 


\section{Blood Hematology}

Blood hematology is a determining indicator of physiological conditions and animalhealth. The number of erythrocytes, hemoglobin and the number of leukocytes in local lamb with forage and concentrate feed treatment in various forms are presented in Table 6.

Table 6 shows that blood erythrocytesdidnot significantly affected by the form of concentrate feed. According to the number of blood erythrocytes remain stable due to homeostasis mechanismin the body of animal. Erythrocyte formation or erythropoiesis process is found in the spinal cord. Erythrocytes are formed from simple proteins in the form of amino acids which previously experienced a catabolic process in the liver. The factor that affects the erythropoiesis process is erythropoeitin, a hormone that affects the activity of the spinal cord. Adequate food intake also supports the formation of erythrocytes.

Table 2: Nutrient content of feed concentrate and field grass

\begin{tabular}{lcrrr}
\hline Nutrient content & Field grass & Mash & Pellet & Wafer \\
\hline Dry matter (\%) & 18.62 & 84.91 & 88.24 & 87.56 \\
Ash (\%) & 14.60 & 9.60 & 10.60 & 10.06 \\
Crude protein (\%) & 9.98 & 15.71 & 15.39 & 14.58 \\
Ether extract (\%) & 2.12 & 3.40 & 3.80 & 3.85 \\
Crude fiber (\%) & 27.33 & 12.79 & 10.45 & 11.47 \\
Nitrogen free extract (\%) & 45.96 & 58.50 & 59.77 & 60.04 \\
TDN (\%) & 58.39 & 64.56 & 64.78 & 64.51 \\
\hline
\end{tabular}

Table 3: Nutrient intake from local lamb for 65 days fed withration containing NSM in different feed forms

\begin{tabular}{|c|c|c|c|}
\hline \multicolumn{4}{|l|}{ Variables } \\
\hline$\overline{\left(\text { g head }^{-1} \text { day }^{-1}\right)}$ & Treatments & & \\
\hline Concentrate intake & Mash & Pellet & Wafer \\
\hline Dry matter & $493.44 \pm 63.14$ & $450.43 \pm 52.15$ & $510.04 \pm 193.55$ \\
\hline Crude protein & $48.80 \pm 6.24$ & $44.55 \pm 5.16$ & $50.44 \pm 19.14$ \\
\hline Ether extract & $10.46 \pm 1.34$ & $9.55 \pm 1.11$ & $10.81 \pm 4.10$ \\
\hline Crude fiber & $134.86 \pm 17.26$ & $123.10 \pm 14.25$ & $139.39 \pm 52.90$ \\
\hline Nitrogen free extract & $226.79 \pm 29.02$ & $207.02 \pm 23.97$ & $234.41 \pm 88.96$ \\
\hline Forage intake & Mash & Pellet & Wafer \\
\hline Dry matter & $864.58 \pm 66.81$ & $696.06 \pm 49.19$ & $804.76 \pm 156.89$ \\
\hline Crude protein & $135.83 \pm 10.50 \mathrm{~b}$ & $107.12 \pm 7.57 \mathrm{a}$ & $117.33 \pm 22.87 \mathrm{ab}$ \\
\hline Ether extract & $29.40 \pm 2.27$ & $26.45 \pm 1.87$ & $30.99 \pm 6.04$ \\
\hline Crude fiber & $110.58 \pm 8.55 b$ & $72.74 \pm 5.14 \mathrm{a}$ & $92.31 \pm 17.99 \mathrm{ab}$ \\
\hline Nitrogen free extract & $505.78 \pm 39.09$ & $416.04 \pm 29.40$ & $483.18 \pm 94.19$ \\
\hline Total intake & Mash & Pellet & Wafer \\
\hline Dry matter & $1358.02 \pm 119.18$ & $1146.49 \pm 95.88$ & $1317 \pm 48 \pm 341.35$ \\
\hline Crude protein & $184.63 \pm 15.45$ & $151.67 \pm 12.06$ & $168.18 \pm 40.78$ \\
\hline Ether extract & $39.86 \pm 3.33$ & $36.00 \pm 2.82$ & $41.90 \pm 9.83$ \\
\hline Crude fiber & $245.44 \pm 23.91$ & $195.84 \pm 18.58$ & $231.97 \pm 69.74$ \\
\hline Nitrogen free extract & $732.57 \pm 62.58$ & $623.05 \pm 50.52$ & $719.24 \pm 177.94$ \\
\hline
\end{tabular}

Table 4: The rate growth of 15 local lamb for 65 days, fed withration containing NSM in different feed forms

\begin{tabular}{llll}
\hline Variables & Treatments & & \\
\hline & Mash & Pellet & Wafer \\
Initial body weight $\left(\mathrm{kg} \mathrm{head}^{-1}\right)$ & $21.20 \pm 4.67$ & $20.63 \pm 1.44$ & $22.84 \pm 3.66$ \\
Final weight $\left(\mathrm{kg} \mathrm{head}^{-1}\right)$ & $29.57 \pm 5.87$ & $28.25 \pm 2.71$ & $30.63 \pm 3.75$ \\
Average dailyweight gain $\left(\mathrm{g} \mathrm{head}^{-1}\right)$ & $120.96 \pm 8.09$ & $117.23 \pm 32.19$ & $119.81 \pm 25.55$ \\
Feed Efficiency $(\%)$ & $8.71 \pm 0.92$ & $9.89 \pm 2.64$ & $9.46 \pm 4.52$ \\
IOFC $\left(\mathrm{Rp} \mathrm{head}^{-1}\right)$ & $336051 \pm 83686$ & $240181 \pm 145317$ & $284299 \pm 139904$ \\
\hline
\end{tabular}

Table 5: Average blood metabolites profile of 15 local lambfed withration containing NSM in different feed forms

\section{Treatments}

\begin{tabular}{lllll} 
Variables & Mash & Pellet & Wafer & Normal level \\
\hline Glucose $\left(\mathrm{mg} \mathrm{dL}^{-1}\right)$ & 71.44 & 81.23 & 75.58 & $50-100^{1}$ \\
Triglycerides $\left(\mathrm{mg} \mathrm{dL}^{-1}\right)$ & $35.88^{\mathrm{b}}$ & $19.46^{\mathrm{a}}$ & $22.66^{\mathrm{ab}}$ & $21-49^{2}$ \\
BUN $\left(\mathrm{mg} \mathrm{dL}^{-1}\right)$ & $24.25^{\mathrm{ab}}$ & $22.28^{\mathrm{a}}$ & $26.27^{\mathrm{b}}$ & $2-34^{3}$ \\
\hline
\end{tabular}


Table 6: Average blood hematology of 15 local lambfed with ration containing NSM in different feed forms

\begin{tabular}{lllll}
\hline & Treatments & & & \\
Variables & Mash & Pellet & Wafer & Normal level \\
\hline Erythrocytes $\left(\right.$ million $\mathrm{mm}^{-3}$ ) & $9.56 \pm 0.68$ & $9.69 \pm 1.04$ & $10.65 \pm 1.33$ & $9-15^{1}$ \\
Hemoglobin $(\mathrm{g} \%)$ & $12.30 \pm 0.72$ & $13.43 \pm 0.61$ & $12.23 \pm 1.11$ & $8-16^{2}$ \\
Leukocytes (thousand $\mathrm{mm}^{-3}$ ) & $9.92 \pm 1.91$ & $9.33 \pm 0.87$ & $10.38 \pm 1.91$ & $4-12^{3}$ \\
\hline
\end{tabular}

The differences of feed forms did not affect on blood hemoglobin of lambs. Blood hemoglobin of local lambs level is still in a normal conditions according to Banks (1993), which is 8-16 g \% which suggests that the form of concentrated feed mash, pellets and wafer does not interfere with the function of hemoglobin in the blood metabolism as an oxygen binder. Hemoglobin has a very important role to carry and regulate oxygen to the body tissues (Jain, 1993). The ability of blood to carry oxygen is generated by the level of hemoglobin in the blood and the chemical characteristics of hemoglobin (Cunningham., 2002). Hemoglobin levels are influenced by the adequacy of nutrients in feed, especially protein in the ration and digestibility, in addition to age, sex and type of animal.

The differences of feed forms did not affect blood leukocytes of lambs. The number of local lamb blood leukocytes in this study is within the normal range according to Kramer (2000), which is 4-12 thousand $\mathrm{mm}^{-3}$. Stated that the fattening lamb that were fed the pellet form had no significant effect on the number of leukocytes. Then, ruminants that fed the wafer form have normal levels of leukocytes, it indicates the absence of infection or inflammation (Retnani et al., 2017). According to Barkah (2017) ration containing the NSM has a low content of to antibacterial substance, which is $0.015 \%$ thus causing an optimal immunity through an increase in the number of leukocytes.

The content of essential amino acids in protein functions as a building block for erythrocytes. Crude protein intake that meets the needs of sheep causes the formation of blood cells to be undisturbed, so that the numbers are still in normal levels. In addition to protein, iron is needed in the formation of hemoglobin as a building block for hemoglobin molecules. The need for vitamins for erythrocyte formation can be divided into two categories: Those required for the formation of hemoglobin and those required for nuclear proliferation and differentiation. Vitamin B6 is required for the formation of hemoglobin and the explanation seems to be the need for pyridoxal phosphate in heme biosynthesis. In addition, folic acid, vitamin B12 and vitamin $\mathrm{C}$ are also needed. A deficiency in these vitamins then causes cells with normal or increased hemoglobin counts but a decrease in the number of cells. Folic acid and B12 appear to function in erythrocyte maturation based on their role in nucleic acid biosynthesis and more specifically in DNA biosynthesis (Dinning, 1962).

\section{Conclusion}

Feeding lamb with ration containing Nigella sativa mealin three different forms has no significant effect on thedry matter intake, intake of ether extract and nitrogen free extract, blood glucose and blood hematology. However, it has a significant effect on the intakeof crude protein and crude fiber, blood triglycerides and blood urea nitrogen. The pelletform give the best feed efficiency compared to mash and waferform, but the different formsdid not affect lamb performance.

\section{Acknowledgement}

The author wish to thank The Ministry of Research and Higher Education Indonesia through the Doctoral Dissertation Research Programwhich have provided fundingduring the research.

\section{Author's Contributions}

Nisa Nurmilati Barkah: Participated in growth performance experiments, coordinated the data-analysis and contributed to the writing of the manuscript.

Yuli Retnani: Organized and supervised the experiment work and wrote the manuscript.

Komang G. Wiryawan: Designed the research plan, supervised and interpreted the data, proofread the manuscript.

Annisa Rosmalia: Participated in blood metabolite profiles experiments, coordinated the data-analysis and contributed to the writing of the manuscript.

\section{Ethics}

This article is original and contains unpublished material. The corresponding author confirms that all of the other authors have read and approved the manuscript and no ethical issues involved.

\section{References}

Ali, M. A., Sayeed, M. A., Alam, M. S., Yeasmin, M. S., Khan, A. M., \& Muhamad, I. I. (2012). Characteristics of oils and nutrient contents of Nigella sativa Linn and Trigonella foenum-graecum seeds. Bulletin of the Chemical Society of Ethiopia, 26(1). https://www.ajol.info/index.php/bcse/article/view/ 72953 
Banks, WJ. (1993). Applied Veterinery Histology. Mosby Inc, Texas.

https://www.cabdirect.org/?target=\%2fcabdirect $\% 2 \mathrm{f}$ abstract\%2f19932288275

Barkah, N. N. (2017). Metabolit dan Profil Darah Domba Lokal yang Diberi Pakan Mengandung Limbah Industri Pengolahan Habbatussauda (Nigella sativa). Thesis, IPB University, Bogor. https://repository.ipb.ac.id/handle/123456789/88105

Barkah, N. N., Retnani, Y., \& Wiryawan, K. G. (2019, March). In vitro study of Nigella sativa meal as protein source and its combination with the readily available carbohydrates for ruminant diet. In IOP Conference Series: Earth and Environmental Science (Vol. 251, No. 1, p. 012056). IOP Publishing. doi.org/10.1088/1755-1315/251/1/012056

Bertipaglia, L. M. A., Fondevila, M., van Laar, H., \& Castrillo, C. (2010). Effect of pelleting and pellet size of a concentrate for intensively reared beef cattle on in vitro fermentation by two different approaches. Anim. Feed Sci. Technol. 159, 88-95.

https:/www.sciencedirect.com/science/article/abs/pi i/S0377840110001781

Broderick, G. A. (1977). Effect of processing on protein utilization by ruminants. In Protein Crosslinking (pp. 531-544). Springer, Boston, MA. https://link.springer.com/chapter/10.1007/978-14757-9113-6_30

Cheikh-Rouhou, S., Besbes, S., Hentati, B., Blecker, C., Deroanne, C., \& Attia, H. (2007). Nigella sativa L.: Chemical composition and physicochemical characteristics of lipid fraction. Food chemistry, 101(2), 673-681. doi.org/0.1016/j.foodchem.2006.02.022

Danes, M. A. C., Chagas, L. J., Pedroso, A. M., \& Santos, F. A. P. (2013). Effect of protein supplementation on milk production and metabolism of dairy cows grazing tropical grass. Journal of Dairy Science, 96(1), 407-419. https://www.sciencedirect.com/science/article/pii/S002 2030212008004

Dinning, J. S. (1962). Nutritional requirements for blood cell formation in experimental animals. Physiological Reviews, 42(1), 169-180. doi.org 10.1152/physrev.1962.42.1.169.

Gustian, R. A. (2017). Pemanfaatan Limbah Industri Pengolahan Habbatusauda (Nigella sativa) Sebagai Pakan Domba Lokal. https://repository.ipb.ac.id/handle/123456789/89209

Hardisari, R., \& Koiriyah, B. (2016). Gambaran Kadar Trigliserida (Metode Gpo-Pap) Pada Sampel Serum dan Plasma EDTA. Journal Teknologi Laboratorium, 5(1), 27-31.

https://www.teknolabjournal.com/index.php/Jtl/ar ticle/view/73
Abadi, I. K. E., Tahmasebi, A. M., Danesh Mesgaran, M., Naserian, A. A., \& Vakili, A. (2015). Effect of dietary crude protein level on UT-B expression and nitrogen efficiency in growing Baluchi male lambs fed low or high concentrate diets. Iranian Journal of Applied Animal Science, 5(2), 323-332.

http://ijas.iaurasht.ac.ir/article_513316.html

Jain, N. C. (1993). Essential of Veterinary Hematology. Leaand Febiger, Philadelphia.

Javaid, A., Nisa, M. U., Sarwar, M., \& Aasif Shahzad, M. (2008). Ruminal characteristics, blood pH, blood urea nitrogen and nitrogen balance in Nili-ravi Buffalo (Bubalus bubalis) bulls fed diets containing various levels of ruminally degradable protein. AsianAustralasian Journal of Animal Sciences, 21(1), 51-58. doi.org/10.4081/ijas.2007.s2.441

Jayanegara, A., Ridla, M., Astuti, D. A., Wiryawan, K. G., Laconi, E. B., \& Nahrowi, N. (2017). Determination of energy and protein requirements of sheep in Indonesia using a meta-analytical approach. Media Peternakan, 40(2), 118-127.

https://journal.ipb.ac.id/index.php/mediapeternakan/ article/view/16203

Karimizadeh, E., Chaji, M., \& Mohammadabadi, T. (2017). Effects of physical form of diet on nutrient digestibility, rumen fermentation, rumination, growth performance and protozoa population of finishing lambs. Animal Nutrition, 3(2), 139-144. doi.org/10.1016/j.aninu.2017.01.004.

Kearl, L. C. (1982). Nutrient requirements of ruminants in developing countries. International Feedstuffs Institute. https://www.cabdirect.org/?target=\%2fcabdirect $\% 2 \mathrm{f}$ abstract\%2f19830744565

Kramer, J. W. (2000). Schlam's Veterinary Hematology. William \& Wilkins, Philadelphia.

Leonardi, C., Stevenson, M., \& Armentano, L. E. (2003). Effect of two levels of crude protein and methionine supplementation on performance of dairy cows. Journal of dairy science, 86(12), 4033-4042. https://www.sciencedirect.com/science/article/pii/S0 022030203740144

Lu, C. D., Kawas, J. R., \& Mahgoub, O. G. (2005). Fibre digestion and utilization in goats. Small Ruminant Research, 60(1-2), 45-52.

https://www.sciencedirect.com/science/article/abs /pii/S0921448805002178

Marks, D. B. (2000). Biokimia Kedokteran Dasar. EGC, Jakarta. ISBN-10: 9794484830.

Martin, W. F., Armstrong, L. E., \& Rodriguez, N. R. (2013). Dietary protein intake and renal function. Clin. Nutr. Interface Between Metab. Diet, Dis. 
McDonald, P., Greenhalgh, J. F. D., Edwards, R., \& Morgan, C. A. (2002). Animal nutrition. 6th edit. New York. ISBN-10: 0582419069.

Nathalie, H. B. A., Reynolds, B. S., Anne, G., Braun, J. P., \& Trumel, C. (2009). Validation of the Medonic CA620/530 Vet 20- $\mu 1$ Microcapillary Sampler System for Hematology Testing of Feline Blood. Journal of veterinary diagnostic investigation, 21(3), 364-368. https://www.cabdirect.org/ $10.1177 / 104063870902100311$

NRC. (2006). Mineral tolerance of animals: 2005. National Academies Press. ISBN-10: 0309096545.

Nocek, J. E. (1997). Bovine acidosis: Implications on laminitis. Journal of dairy science, 80(5), 1005-1028. https://www.sciencedirect.com/science/article/pii/S0 022030297760260

Norrapoke, T., Wanapat, M., \& Wanapat, S. (2012). Effects of protein level and mangosteen peel pellets (Mago-pel) in concentrate diets on rumen fermentation and milk production in lactating dairy crossbreds. Asian-Australasian journal of animal sciences, 25(7), 971.

https://www.ncbi.nlm.nih.gov/pmc/articles/PMC4 092972/

Novia, D., Amelia, S., \& Ayuza, N. Z. (2011). Kajian suhu pengovenan terhadap kadar protein dan nilai organoleptik telur asin. Jurnal Peternakan, 8(2). http://ejournal.uin-

suska.ac.id/index.php/peternakan/article/viewFile/ 200/186

Porter, J. C., Warner, R. G., \& Kertz, A. F. (2007). Effect of fiber level and physical form of starter on growth and development of dairy calves fed no forage. The professional animal scientist, 23(4), 395-400. https://www.sciencedirect.com/science/article/abs/pi i/S1080744615309943

Ranjhan, SK. 1977. Animal Nutrition and Feeding Practices in India. Vikas Publishing House PVT Ltd, New Delhi. https://agris.fao.org/agrissearch/search.do?recordID $=$ XF2016026010

Retnani, Y., Barkah, N. N., \& Saenab, A. (2020). Processing Technology of Feed Wafer to Increase Feed Production and Efficiency. WARTAZOA. Indonesian Bulletin of Animal and Veterinary Sciences, 30(1), 37-50. http://medpub.litbang.pertanian.go.id/index.php/wartaz oa/article/view/2473

Retnani, Y., Suharti, S., Khotijah, L., Prihantoro, I., Herni, H., \& Argadyasto, D. (2017). The evaluation of wafer feed supplement containing leucaena leaf on pasundan calves. In International Seminar on Tropical Animal Production (ISTAP) (pp. 62-67). https://journal.ugm.ac.id/istapproceeding/article/vie w/29820
Salazar-Villanea, S., Hendriks, W. H., Bruininx, E. M. A. M., Gruppen, H., \& Van Der Poel, A. F. B. (2016). Protein structural changes during processing of vegetable feed ingredients used in swine diets: implications for nutritional value. Nutrition research reviews, 29(1), 126-141.

Sastradipradja, D., Sikar, S. H. S., Widjayakusuma, R., Maad, T., Unandar, N. H., Suriawinata, R., \& Hamzah, K. (1989). Penuntun Praktikum Fisiologi Veteriner. IPB Pr, Bogor.

Soehardi, S. (2004). Memelihara kesehatan jasmani melalui makanan. Bandung: ITB.

Solanas, E., Castrillo, C., Serrano, X., Janacua, H., Fondevila, M., \& Guada, J. A. (2005). Effect of concentrate extrusion and castration on diet digestion and performance of intensively reared male calves. Livestock Production Science, 94(3), 225-236. doi.org/10.1016/j.livprodsci.2004.12.003.

Subiyono, M. M. A., \& Gabrela, D. (2016). Gambaran kadar glukosa darah metode GOD-PAP (glucose oxsidaseperoxidase aminoantypirin) sample serum dan plasma EDTA (ethylen diamin terta acetat). Teknolab 5(1), 4548. ISSN-10: 2338-5634.

Svihus, B., Uhlen, A. K., \& Harstad, O. M. (2005). Effect of starch granule structure, associated components and processing on nutritive value of cereal starch: A review. Animal Feed Science and Technology, 122(3-4), 303-320. doi.org/10.1016/j.anifeedsci.2005.02.025

Tillman, A. D., Hartadi, H., Reksohadiprodjo, S., Prawirokusumo, S., \& Lebdosoekojo, S. (1998). Ilmu makanan ternak dasar.

Trisyulianti, E., Jacja, J., \& Jayusmar, (2001). Effect of pressing temperature and pressure on the physical properties of agricultural waste ration wafers from fiber and legume sources for ruminants. Med. Pet. 24(3), 76-81.

https://journal.ipb.ac.id/index.php/mediapeternakan/ article/view/12031

Tsalissavrina, I., \& Wahono, D. handayani D. (2006). Pengaruh Pemberian Diet Tinggi Karbohidrat Dibandingkan Diet Tinggi Lemak Terhadap Kadar Trigliserida dan HDL Darah pada Rattus novergicus galur wistar. Jurnal Kedokteran Brawijaya, 22(2), 81-90. doi.org/10.21776/ub.jkb.2006.022.02.5

Widihastono, B. (1993). Biosensor Untuk Analisis Urea Berdasarkan Pada Aplikasi Enzim Urease Dan Elektroda Tungsten. Jurnal Kimia Terapan Indonesia (Indonesian Journal of Applied Chemistry), 3(1). doi.org/10.14203/jkti.v3i1.298 